\title{
Pasolini e o fim: o lugar da literatura em tempos de consumo
}

\section{Pasolini and the end: literature's role in times of consumerism}

Davi Andrade Pimentel

davi_a_pimentel@yahoo.com.br

Universidade Federal do Rio de Janeiro

RESUMO: Com base na leitura de Escritos corsários e de A nebulosa, de Pier Paolo Pasolini, este artigo pretende desenvolver dois movimentos de reflexão sobre o lugar da literatura em nossa contemporaneidade: o primeiro, como a crítica jornalística de Pasolini à sociedade de consumo pode vir a nos auxiliar a pensar sobre o lugar atual da literatura em nossa sociedade; e, o segundo, como o trágico, enquanto elemento estético retomado pela fiç̧ão de Pasolini, se caracteriza como crítica à classe burguesa e como mecanismo de escrita para o estabelecimento de um lugar para a literatura em nosso presente.

PALAVRAS-CHAVE: Pier Paolo Pasolini. Sociedade de consumo. Tragédia moderna.

ABSTRACT: Based on the reading of Pier Paolo Pasolini's Corsair Writings and La nebbiosa, this article aims to develop two movements that may lead us to think about literature's role in the contemporary times: the first one relates to how Pasolini's journalistic criticism on consumer society may end up for assisting us to think about the current role of literature in our society; and the second one that reflects on how the tragic, as an aesthetic element that is retook through Pasolini's fiction, is characterized as a critic to the bourgeoisie and as a writing mechanism to the establishment of literature's role at the current moment.

KEYWORDS: Pier Paolo Pasolini. Consumer society. Modern tragedy.

\section{Notas sobre um futuro negativo ou o "fim de tudo"}

Como um rio que transborda, precipitam-se para a saída, deixando atrás de si a catástrofe.

(Pasolini, A nebulosa, 2016)

\footnotetext{
* Graduado em Letras-Literaturas pela Universidade Federal do Ceará - UFC. Mestre em Literatura Brasileira pela Universidade Federal do Ceará - UFC. Doutor em Literatura Comparada pela Universidade Federal Fluminense - UFF. Pós-doutor em Literatura/Tradução pela Universidade Federal Fluminense - UFF. Pós-doutorando sênior em Literatura/Tradução pela Universidade Federal do Rio de Janeiro - UFRJ.
} 


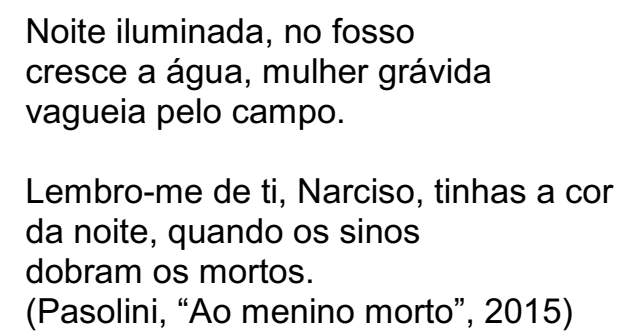

Decerto, hoje, articularmos ideias sobre o fim parecerá um tanto sintomático - e, na verdade, o é. Em tempos de pandemia, nos quais a nossa civilização, apesar de seus contundentes recursos tecnológicos, se encontra em desvantagem diante de um vírus em constante mutação, quando obrigatoriamente nos é tolhida parte de nossa liberdade, quando parentes sucumbem ao vírus e quando do outro é preciso que nos afastemos, a ideia do fim se torna uma ideia cada vez mais presente e mais necessária. Infelizmente, ou felizmente, se soubermos escutá-la, a literatura, desde o seu primeiro escrito, pressagia, de modos diversos, o fim, seja da natureza, do homem ou dela própria. Como um oráculo intermitente, com poucas ou longas pausas, ela vaticina o tempo escatológico. Todavia, como Édipos, muitas vezes não a compreendemos ou a entendemos mal ou sequer a escutamos, embora saibamos 0 fim do Rei de Tebas. Essa incompreensão se torna mais profunda principalmente quando da ascensão do regime capitalista e do seu modus operandi de consumo que, como afirma acertadamente Pier Paolo Pasolini, em "Análise linguística de um slogan", texto presente em Escritos corsários, ${ }^{1}$ se destaca como "um mundo inexpressivo, sem particularismos nem diversidade de culturas, perfeitamente padronizado e aculturado" (PASOLINI, 2020, p. 42-3). Em um momento posterior de seu texto, Pasolini, tomando como base de seu pensamento as transformações na propaganda industrial, refere-se, em 1973, a um futuro sombrio, no qual a língua humanista cederia lugar à língua tecnicista, a língua do consumo. E finaliza o parágrafo com o seguinte sortilégio da lógica: "parece ser um mundo de morte" (PASOLINI, 2020, p. 43). A partir de uma reflexão sobre a linguagem comunicativa da indústria, Pasolini pressagia, assim como o seu narrador de $A$ nebulosa, ${ }^{2}$ um futuro negativo: "No céu plúmbeo, vislumbra-se um presságio penoso, mortal, do dia que nasce" (PASOLINI, 2016, p. 193).

\footnotetext{
1 Salvo os livros Poemas e A nebulosa, os demais textos de Pier Paolo Pasolini citados ao longo deste artigo pertencem ao livro Escritos corsários.

2 Em se tratando de uma edição portuguesa, optou-se por manter a grafia original das palavras.
} 
Em uma aproximação com a literatura está a linguagem humanista referida por Pasolini em seu texto, uma linguagem da ordem da mutabilidade eterna e da interpretação infinita, que, por essa razão, vem a se opor à linguagem da técnica, voltada exclusivamente ao pragmatismo do consumo, sendo rígida e modelar. Por mais que o crítico projete uma visão menos pessimista do futuro após nos atordoar com o choque de um futuro de morte, o que se segue é um panorama do futuro enquanto negatividade, como veremos também nos demais textos de Escritos corsários: "O novo poder burguês, de fato, requer dos consumidores um espírito totalmente pragmático e hedonista: só num universo tecnicista e puramente terreno o ciclo da produção e do consumo pode se realizar segundo sua própria natureza" (PASOLINI, 2020, p. 45). Pasolini, enquanto profeta da modernidade, previu o futuro do mundo, ou melhor, o nosso presente. Em um mundo no qual reina a padronização e o sistema de aculturação, a literatura tende a ser desprezada, difamada ou ridicularizada. O oráculo tende a ser coberto por tempo indeterminado. Em "Aculturação e aculturação", Pasolini comenta que uma das consequências mais comuns do sistema da sociedade de consumo, excitada pelo capitalismo, é a drástica mudança de perspectiva em relação à cultura daqueles que pertencem tanto à classe subproletária quanto à classe pequeno-burguesa: em ambas, a cultura sai em desvantagem, relegada a um plano cada vez mais inferior. Se, por um lado, os primeiros, em sua maioria, respeitavam a cultura e não se envergonhavam de sua suposta ignorância, agora, para se adequarem ao novo modelo estilo pequenoburguês propagado pelo consumo, em que rusticidade e analfabetismo para nada valem, e, consequentemente, não podendo absorver de modo substancial e rápido a cultura, se veem como aqueles que a desprezam, sobretudo no que se refere à literatura e a outras artes, salvo o cinema comercial.

Por outro lado, os pequeno-burgueses, para os quais a propaganda e o idílio hedonista são planejados, se veem, por sua vez, infelizes, pois a técnica e a modelagem capitalista coíbem o "homem natural" presente neles aflorar, não lhes permitindo regressar ao "bucolismo" dos primeiros tempos. A esse interdito, como modo de punição à sua classe, os pequeno-burgueses tendem a apresentar um retraimento de suas faculdades intelectuais e morais, ou seja, tendem a desprezar, a seu modo, a cultura: "Se os subproletários se aburguesaram, os burgueses por sua vez se subproletarizaram" (PASOLINI, 2020, p. 55). Nesse cenário, que, por sinal, nos é bastante próximo e atual, a literatura não encontra um lugar de acolhida, sendo 
preciso, para que o oráculo mais uma vez seja posto em seu devido lugar, eventos catastróficos ou calamidades públicas, como a que estamos enfrentando hoje, com a pandemia de Covid-19, para que nos voltemos novamente à literatura. Isolados, como estamos agora, a humanidade, perdida com o desprezo pela cultura e pelo outro, aflora. O humano que nos faz humano ressurge em tempos adversos. Dito isto, nada mais premonitório do que $A$ peste, de Albert Camus: "O flagelo não está à altura do homem; diz-se então que o flagelo é irreal, que é um sonho mau que vai passar. Mas nem sempre ele passa e, de sonho mau em sonho mau, são os homens que passam e os humanistas em primeiro lugar, pois não tomaram as suas precauções" (CAMUS, 2018, p. 40). No início da pandemia, as edições de $A$ peste logo se esgotaram em grande parte da Europa, embora talvez já fosse um tanto tarde para aqueles que buscavam naquele momento e, sobretudo, hoje, compreender o oráculo camusiano: Édipo já desposara Jocasta. Trechos de A peste, tais como: "Toda a cidade estava com febre", "Fechem a cidade", "longo tempo de exílio" e "A peste tornara-se então pulmonar", podem ser facilmente deslocados para os textos jornalísticos atuais, que noticiam, mesmo após passados quase dez meses da pandemia, a propagação e as consequências para a sociedade da Covid-19, tamanha a equivalência entre a peste e o vírus.

Porém, uma vez mais a calamidade tomando conta das cidades, o homem moderno, sem ter devidamente se precavido, se encontra diante de uma nova Esfinge, para a qual não tem resposta - custa-lhe ver que a saída se encontra novamente na figura do próprio homem: " "Senhor supremo, ajuda agora, Édipo,/ pois todos clamam, todos te suplicam/ uma saída: acaso um deus, um homem/ não disse como nos mantermos vivos?" (SÓFOCLES, 2016, p. 40). Para o não se tem resposta do homem moderno, o narrador de $A$ peste diz que a origem de seu problema se encontra na

\footnotetext{
${ }^{3}$ Principalmente quando temos um presidente negacionista que irresponsavelmente omite os dados reais da propagação do vírus, das mortes pelo vírus e procrastina em uma disputa política a liberação de verbas para a compra de insumos para futuras vacinas, bem como insiste em querer embargar as vacinas vindas da China por pura ideologia canhestra. Mas, há ainda, um dado mais alarmante publicado pelo jornal O Estado de S. Paulo, de 22 de novembro de 2020, que confirma não apenas o despreparo do Governo Federal como, sobretudo, confirma as suas táticas abjetas para se coibir qualquer realidade do Covid-19, pois um "total de 6,86 milhões de testes para o diagnóstico do novo coronavírus comprados pelo Ministério da Saúde perde a validade entre dezembro deste ano e janeiro de 2021. Esses exames RT-PCR estão estocados num armazém do governo federal em Guarulhos e, até hoje, não foram distribuídos para a rede pública" (VARGAS, 2020). Ora, se não existe o vírus, não há a necessidade de se fechar o comércio e desacelerar a economia. E, mais uma vez, o capital dita as regras. Porém, sejamos sinceros, um capital pessimamente administrado pelo Governo Federal, que não acompanha a realidade de outras potências mundiais quando se trata de tentar equilibrar pandemia e economia.
} 
ignorância, que logo o conduzirá a um despreparo frente a uma possibilidade catastrófica futura: "O mal que existe no mundo provém quase sempre da ignorância, e a boa vontade, se não for esclarecida, pode causar tantos danos quanto a maldade" (CAMUS, 2018, p. 125). Pasolini, por sua vez, credita o não se tem resposta catastrófico ao consumo: "Nenhum centralismo fascista conseguiu fazer o que fez o centralismo da sociedade de consumo. [...] É possível portanto afirmar que a 'tolerância' da ideologia hedonista desejada pelo novo poder é a pior das repressões da história humana" (PASOLINI, 2020, p. 53-54). De um lado, a ignorância, do outro, o consumo, e diante deles o homem e o não saber. Consumo e ignorância, longe de serem posicionados em polos opostos, são, na verdade, faces de uma mesma moeda, uma moeda cujo valor entorpecedor corrompe a sociedade moderna, a começar por sua base: "Um hedonismo neolaico, cegamente esquecido de qualquer valor humanista e cegamente alheio às ciências humanas" (PASOLINI, 2020, p. 54). Na perspectiva de Jean Baudrillard, em $A$ sociedade de consumo, ${ }^{4}$ esse hedonismo neolaico, que resulta da prática do consumo capitalista, é visto como um processo de mutação na "ecologia da espécie humana", pois a relação com o objeto, e com o seu valor de venda e de troca, substituirá cada vez mais, na sociedade de consumo, as relações humanas. Ou seja, em curtíssimo prazo, não haverá mais o eu e o humano, mas o eu e o objeto (ou o eu-objeto e o objeto) - parafraseando Descartes, "tenho um objeto, logo existirei enquanto também objeto":

À nossa volta, existe hoje uma espécie de evidência fantástica do consumo e da abundância, criada pela multiplicação dos objectos, dos serviços, dos bens materiais, originando como que uma categoria de mutação fundamental na ecologia da espécie humana. Para falar com propriedade, os homens da opulência não se encontram rodeados, como sempre acontecera, por outros homens, mas mais por objectos. O conjunto das suas relações sociais já não é tanto o laço com os seus semelhantes quanto, no plano estatístico segundo uma curva ascendente, a recepção e a manipulação de bens [...] Vivemos o tempo dos objectos: quero dizer que existimos segundo o seu ritmo e em conformidade com a sua sucessão permanente. (BAUDRILLARD, 1995 , p. 15, grifo do autor)

É fundamental para uma sociedade de consumo o objeto - produzi-lo, vendê-lo e/ou trocá-lo. Porém, para o capitalismo, é preciso que esse objeto exceda a necessidade vital do humano (alimentação, vestimenta e moradia, por exemplo) para

\footnotetext{
${ }^{4}$ Em se tratando de uma edição portuguesa, optou-se por manter a grafia original das palavras.
} 
se tornar objeto de consumo, muitas vezes, objeto desnecessário, supérfluo e prescindível à vida humana, uma vez que, no capital, o que o movimenta é o dinheiro e, como bem destaca Isleide Arruda Fontenelle, em seu artigo "O estatuto do consumo na compreensão da lógica e das mutações do capitalismo", a sua circulação: "Sem isso, sem a circulação de dinheiro como capital, não existe capitalismo" (FONTENELLE, 2014, p. 210). E dessa circulação resulta, como já havia escrito Pasolini, em Escritos corsários, a objetificação do humano. O regime capitalista sobrevive em nossa modernidade a partir de um fluxo contínuo de mercadorias que, com base em slogans sugestivamente sedutores, emulam no homem o consumo, como se, para fazer parte da sociedade, fosse necessário, e o é, adquirir bens, ter bens, ainda que não tenhamos os recursos necessários para consumi-los: "Frustração ou verdadeira ansiedade neurótica são hoje estados de espírito coletivos" (PASOLINI, 2020, p. 54). No capital, o que está em jogo não é mais a necessidade vital do humano, muito menos as relações reais entre os seres, mas, retomando Baudrillard, a relação com o objeto e a (re)produção do dinheiro e, sobretudo, a sua fábrica de ilusões. $O$ filósofo esloveno Slavoj Žižek, em $A$ visão em paralaxe, nos diz que o capitalismo se fundamenta em ilusões, desde o campo da produção até o campo do consumo, que assim o fazem operar e reverberar a sua cadeia de ilusões, tendo sempre como meta o dinheiro:

Em resumo, capital é dinheiro que não é mais mera substância de riqueza, sua personificação universal, mas valor que, por meio da circulação, gera mais valor, valor que se media e se postula, postulando retroativamente seus próprios pressupostos [...] a partir desse momento, a verdadeira meta não é mais a satisfação de necessidades individuais, mas simplesmente mais dinheiro, a repetição interminável da circulação enquanto tal... (ŽlŽEK, 2008, p. 87-88)

No capital, o dinheiro se destaca, pois o verbo usar, após a revolução industrial, como afirma Hannah Arendt, em $A$ condição humana, foi substituído pelo verbo consumir: "A revolução industrial substituiu todo artesanato pelo labor; o resultado foi que as coisas do mundo moderno se tornaram produtos do labor, cujo destino natural é serem consumidos, ao invés de produtos do trabalho, que se destinam a ser usados" (ARENDT, 2007, p. 137). A partir de então, as mercadorias foram continuamente substituídas para que a moeda do capital não fosse desvalorizada e não entrasse em colapso. O ter e o possuir logo se apresentaram como a grande doença neurótica do 
homem, uma vez que apenas uma pequena parcela da humanidade poderia, e pode, acompanhar de fato o "progresso capitalista", ou melhor, as novidades diárias do mercado. Para a grande parcela, resta-lhe um mimetismo que a torna ora vítima, ora caricatura, ora vítima caricatural do modelo pequeno-burguês emulado pelo capitalismo. Como consequência desse novo poder, como observa Pasolini com bastante lucidez, em 1973, em “Aculturação e aculturação", tem-se o desprezo pelas ciências humanas, a literatura aqui em especial. Por quê? Devido à alta rotatividade das mercadorias em tempos capitalistas, não há espaço para o demorar-se em um determinado objeto, neste caso, o livro. O pensar e o refletir, por demandarem bastante tempo, não são justificáveis e aproveitáveis pelo capital, pois o demorar-se provocaria uma lentidão em seu sistema de consumo, haveria o acúmulo de mercadorias, a perda de dinheiro e a consequente desvalorização de sua moeda. Contudo, para além da perda monetária, o regime capitalista tem uma razão maior para tentar reduzir a cultura a quase nada. Estamos de acordo que o capitalismo se torna o novo poder da sociedade moderna tendo como suportes o dinheiro, o consumo e a perecibilidade. $\mathrm{E}$, em nenhum deles, notemos, há o pensamento ou a reflexão, pois o torpor consumista exige do ser a desaceleração de sua inteligência e a consequente robotização de sua estrutura hominídea para fins de consumo sem questionamentos, que, por sua vez, transforma-o em um ser ignorante ou, nas palavras de Pasolini, em "Vazio de Caridade, vazio de Cultura: uma linguagem sem origens”, de 1974, em um homem-massa: “A noção de 'indivíduo' é por sua natureza contraditória e inconciliável com as exigências do consumo. É preciso destruir o indivíduo. Ele deve ser substituído (como se sabe) pelo homem-massa" (PASOLINI, 2020, p. 68).

O conceito de homem-massa explorado por Pasolini ecoa, em semelhante proposta, o conceito de homem-rebanho apresentado por Nietzsche em Além do bem e do mal: "A espiritualidade superior e independente, a vontade de estar só e mesmo a grande razão serão percebidas como perigo: tudo o que ergue o indivíduo acima do rebanho e infunde temor ao próximo é doravante apelidado de mau" (NIETZSCHE, 2005, p. 88, grifo do autor). O mau, em uma sociedade de consumo, é o ser diferente ou é aquele indivíduo que, por escolha própria, abdicou do "hedonismo que se tornou a nova religião" (PASOLINI, 2020, p. 68). A diferença escapa à padronização, logo, ao jogo do consumo, por isso a extrema necessidade do regime capitalista de incorporar ou de afastar ou de suprimir toda e qualquer diferença. Embora os 
diferentes $^{5}$ de nossa sociedade, como os LGBTQI+, os negros, os índios e as mulheres, consumam e sejam excelentes consumidores, ainda assim, o sistema capitalista, implacavelmente, exerce um movimento de supressão da diferença escamoteado por uma ideia de tolerância das diferenças: "É essa tolerância do poder [...] que deve ser analisada e desmascarada. É ela, em última instância, a razão de toda uma série de equívocos e de erros de visão (moral, ideológica, política)" (PASOLINI, 2020, p. 238). Em "A prisão e a fraternidade do amor homossexual", Pasolini expõe a sua completa descrença à tolerância da sociedade de consumo, dando como exemplo os homossexuais, que nunca realmente foram incorporados de fato ao sistema social da burguesia: "O homossexual e a homossexualidade são vistos como formas do 'Mal', mas de um 'Mal' recalcado e transferido para um lugar onde é 'Outro'; ou seja, onde se torna monstruoso, demoníaco, degradante" (PASOLINI, 2020, p. 239).

A literatura faz do homem o que Nietzsche, em Além do bem e do mal, nomeia de espírito livre, em clara oposição ao homem-rebanho: "Independência é algo para bem poucos: - é prerrogativa dos fortes. E quem procura ser independente sem ter a obrigação disso, ainda que com todo o direito, demonstra que provavelmente é não apenas forte, mas temerário além de qualquer medida" (NIETZSCHE, 2005, p. 34, grifo do autor). Independência e individualidade, duas das principais características do homem de espírito livre, são continuamente reprimidas pelo sistema capitalista, uma vez que ser livre, ou melhor, ter a consciência livre, acarreta ter o poder de escolha, de decisão e de dispêndio face ao consumismo proposto por nossa sociedade regida pelo capital. É por essa razão que a independência figura como uma característica que precisa ser descreditada ou ridicularizada para que, como um vírus, não contamine boa parte do rebanho: "Tudo bem: minha ótica talvez seja mesmo a de um 'artista', isto é, como quer a boa burguesia, de um doido" (PASOLINI, 2020, p. 80). Aqueles que procuram fazer resistência frente ao sistema, seja ele político ou econômico, logo ganham a alcunha, depreciativa, acredita-se, de "artista", o que não deixa de ser interessante, pois, na história da humanidade, sempre foram os artistas que de imediato fizeram resistência a toda e qualquer injustiça social, foram os

\footnotetext{
${ }^{5}$ Neste artigo, a palavra diferente é uma provocação, baseada no livro Explosão feminista, organizado por Heloisa Buarque de Hollanda, para refletirmos sobre a atual padronização de nossa sociedade brasileira, que se funda em três pilares: na heterossexualidade (orientação sexual), no masculino (gênero) e na pele branca (raça).
} 
primeiros, por exemplo, a denunciarem as formas abjetas do racismo, e são eles que mantêm inabalável o direito do homem pensar por seu próprio intelecto. Ser artista é, antes de tudo, ter a coragem de Pasolini que, em 1974, por meio de seu artigomanifesto, "O romance dos massacres", escreveu forte e belissimamente: "Eu sei os nomes dos responsáveis por aquilo que vem sendo chamado de 'golpe' (e que na verdade é uma série de 'golpes' instituídos como sistema de proteção do poder)" (PASOLINI, 2020, p. 120).

O artigo-manifesto "O romance dos massacres" é de uma poeticidade arrebatadora que faz tremer o "rosto ainda em branco do novo Poder" (PASOLINI, 2020, p. 79), tamanha a sua impetuosidade em enfrentar, desmascarar e denunciar os crimes e atentados do "novo Poder" à época: "Eu sei, portanto, os nomes da 'cúpula' que manobrou tanto os velhos fascistas idealizadores dos golpes, como os neofascistas autores materiais dos primeiros atentados, como ainda os 'desconhecidos' autores materiais dos atentados mais recentes” (PASOLINI, 2020, p. 121, grifo do autor). Um poema-artigo todo ritmado a partir da repetição do sintagma "Eu sei", que, a cada estrofe-parágrafo, agrega uma força de luta e de resistência, de verdade a ser conquistada e dita, sem meios termos. Através da potência lírica presente em "O romance dos massacres", o leitor de hoje recebe uma contundente força para fazer resistência frente a um Governo que pretende a todo custo dizimar a cultura, padronizar os costumes e alienar a população. Desse modo, Pasolini nos convida e nos incentiva a denunciar com um "Eu sei" próprio, nosso, essas constantes tentativas de repressão e de coação perpetradas por nosso Presidente: "Eu sei todos esses nomes e sei de todos os fatos (atentados a instituições e massacres) dos quais eles são culpados" (PASOLINI, 2020, p. 122). "O romance dos massacres" se apresenta, então, como um poema engajado. Como bom artista radical que fora, Pasolini subverte a lógica do poema, transformando a estrutura de seu artigo em um poema em prosa - um poema cujo entusiasmo se encontra na utopia socialista: "Mas não existe só o poder: existe também uma oposição ao poder. Essa oposição ao poder na Itália é tão vasta e forte que constitui um poder em si mesma: me refiro naturalmente ao Partido Comunista Italiano" (PASOLINI, 2020, p. 124). Como pudemos testemunhar ao longo deste artigo, a posição crítica de Pasolini ao centralismo da sociedade de consumo se deu, de modo bastante coerente, "através da minha ótica pessoal, que é a de um comunista" (PASOLINI, 2020, p. 125). 
Após lermos Pasolini, acredito que tenhamos uma resposta para o não se tem resposta do homem moderno: a cultura. Se seguirmos os seus passos, saberemos que a arma mais eficaz contra a padronização, o hedonismo e o consumo, que deterioram a alma humana, é a inteligência fomentada pela cultura. Enquanto crítico, cineasta e escritor, Pasolini se tornou um exemplo de que só a cultura de um homem pode salvá-lo de ser devorado pela ignorância consumista. Um consumo que, como ficou atestado, escraviza, ilude e mata os homens: "Mas é possível prever um mundo tão negativo? É possível prever um futuro como 'fim de tudo'?" (PASOLINI, 2020, p. 43). À pergunta de Pasolini, caso nos demoremos a observar o nosso entorno político, social e econômico atual, poderíamos responder que sim, que é possível prever um mundo tão negativo. Todavia, se pudermos resistir, como estamos fazendo agora e como sempre fizemos, é possível contornar esse fim escatológico alimentando o espírito dos homens com cultura, e não com o consumo ou com armas de fogo. $\mathrm{Na}$ leitura de Escritos corsários, fica patente que o futuro previsto por Pasolini, ou seja, o nosso hoje, poderia ter sido evitado, caso, claro, tivéssemos dado ouvidos à sua voz profética e à voz oracular da literatura.

\title{
2 A nebulosa, de Pasolini, e o seu fim trágico
}

\author{
Pouco mais que corpo, ó futuros \\ Vivos que vivereis em meu lugar \\ na tepidez destes muros, \\ já não conheço em mim outro amor \\ que não o Azul dos dias escuros, \\ o tempo nada mais é que Azul \\ atrás dos ombros do moribundo, \\ uma paisagem suave e estéril, \\ um obsessivo sussurro, \\ física imagem sobre o Nada. \\ (Pasolini, "Balada do delírio", 2015)
}

Enquanto metáfora de um destino negativo ou do "fim de tudo", A nebulosa, de Pasolini, concentra um movimento de escrita importante para a literatura em tempos modernos e de consumo: a sua constituição textual trágica, no sentido estético do termo trágico. O texto de $A$ nebulosa foi inicialmente originado como argumento para a realização de um filme que, por várias razões, fora interrompido e logo depois retomado, mas com o argumento de Pasolini modificado profundamente, pelos jovens realizadores Gian Rocco e Pino Serpi. O resultado fílmico final se mostrou um grande fracasso: "Milano nera - o título final do filme para cujo guião Pasolini fora chamado - 
foi exibido em Setembro de 1963, numa única sala da capital lombarda, e esteve apenas cinco dias em cartaz. Um fiasco" (PICCININI, 2016, 08). Apenas em 1995, o texto final de A nebulosa, agora no formato de romance, é retirado do esquecimento e ganha uma análise crítica mais relevante. Como se estivéssemos diante do script de um filme, o romance de Pasolini, somado a um enredo sobre uma gangue de teddy boys italiana que busca se vingar da sociedade pequeno-burguesa a partir de pequenos e grandes atos de violência, nos apresenta um texto todo estruturado no formato de roteiro, com instruções que caberiam mais a um ator ou a um diretor de cinema do que propriamente a um leitor. São instruções sobre a locação da cena, se em um ambiente interior ou exterior, sobre como as câmeras devem se posicionar diante do personagem, se enquadrada ou em grande plano, e, por fim, sobre como deve ser o físico e as roupas dos personagens. No entanto, em sua estrutura cinematográfica, na qual as informações são, por vezes, excessivas, pois quase não deixam espaço para a imaginação do leitor, ocorre um impasse: não podemos afirmar que se trata realmente de um roteiro, nem simplesmente que se trata de um romance.

Adotando certamente as ideias de Victor Hugo, ${ }^{6}$ presentes em seu prefáciomanifesto Do grotesco e do sublime, Pasolini constrói um romance híbrido, no qual se misturam vertiginosamente o espírito literário moderno, com seus empréstimos técnicos provindos da arte cinematográfica, e o espírito melancólico, por vezes pessimista, de uma literatura mais clássica, quando nos deparamos com um narrador que ora cede a refletir sobre as ações de seus personagens, ora comenta sobre a época caótica de uma Itália em convulsão, ora devassa a psique de seus teddy boys para dar-lhes um ar humano em meio a virulência aparente de seus atos. Um hibridismo literário que torna ainda mais complexa a análise de sua obra, embora seja esse hibridismo que a torne, por outro lado, uma experiência única que nos leva a vislumbrar, na constante tensão dos gêneros literários, uma Milão burguesa em declínio, grotesca, atormentada, perdida, porém, bela, desejosa e apaixonante: "Uma

\footnotetext{
${ }^{6}$ Em defesa de uma arte literária liberta de padrões e das regras clássicas instituídas pelas poéticas gregas e latinas, Victor Hugo, em Do grotesco e do sublime, reclama para a sua época um fazer literário que rompa com o classicismo e que assuma a sua modernidade, no que se refere ao hibridismo dos gêneros literários, impensável na tradição clássica, e à individualidade do artista. Segundo Hugo, o artista, ao deixar de seguir um modelo e ao apostar no que o inspira, se apresentará único e dará ao seu tempo uma visão de mundo e de literatura diferenciada e enriquecedora, e não mais padronizada: "- Voltemos pois, e tentemos fazer ver que é da fecunda união do tipo grotesco com o tipo sublime que nasce o gênio moderno, tão complexo, tão variado nas suas formas, tão inesgotável nas suas criações, e nisto bem oposto à uniforme simplicidade do gênio antigo; mostremos que é daí que é preciso partir para estabelecer a radical e real diferença entre as duas literaturas" (HUGO, 2014, p. 28).
} 
imagem impressionante da Milão noturna [...] Por trás deste aglomerado de ruínas, resplandecem as silhuetas de quatro ou cinco arranha-céus: o Galfa, o Pirelli, etc. [...] Pois é, também o progresso tem as suas belezas..." (PASOLINI, 2016, p. 87). Esse olhar que se demora na ruína e que vê nela o reflexo de uma sociedade que se corrompeu, que vendeu a sua alma ao consumo e que, por isso, está chegando ao seu fim humano, é uma chaga aberta que percorrerá grande parte da obra de Pasolini.

Em "Pasolini escritor-crítico em Descrizioni di descrizioni", Maria Betânia Amoroso reflete de modo bastante significativo sobre o vocabulário de Pasolini que, neste artigo, está representado por $A$ nebulosa, como veremos a seguir. Diz Amoroso: 'Seu vocabulário crítico é feito de palavras como 'destino', 'sinceridade', 'escândalo', 'violência', 'experiência'. A sinceridade é posta em relação direta com a 'pesquisa escandalosa' sobre o próprio destino (e aqui temos muito de Freud lido por Pasolini) e exige a completa descida aos infernos - outro tema, outra palavra constante de seu vocabulário crítico e ficcional" (AMOROSO, 2016, p. 101). Tanto a perspectiva do destino trágico quanto a perspectiva da violência desmedida, ambas relacionadas à sociedade burguesa, se concentram em A nebulosa, por exemplo, na fala de Rospo, o chefe da gangue dos teddy boys, ao se referir às senhoras casadas que cederam sexualmente às investidas do grupo: "Têm dinheiro, peles... os maridinhos que se esfalfam a trabalhar e ganham milhões à custa dos pobres desgraçados... Divertemse com quem Ihes dá na veneta, esquecendo-se da argola que usam no dedo" (PASOLINI, 2016, p. 120). Em "Ampliação do 'esboço' sobre a revolução antropológica na Itália", de Escritos corsários, Pasolini assume a sua visão escatológica, já comentada no início deste artigo: "Não quero fazer profecias, mas não escondo que sou desesperadamente pessimista" (PASOLINI, 2020, p. 92).

Essa visão em ruínas de Pasolini sobre a burguesia italiana, que se espalha como um tecido cancerígeno por todo o texto de $A$ nebulosa, constitui-se como uma visão trágica própria da modernidade, como confirma Terry Eagleton, em Doce violência: a ideia do trágico: "O que acontece com a tragédia no século $X X$ não é a sua morte, mas sua transformação em modernismo, pois uma importante linha do modernismo [...] também ridiculariza uma sociedade de classe média da qual, não obstante, ela se mantém cúmplice" (EAGLETON, 2013, p. 285). Rospo e sua gangue, como os mitológicos Argonautas à procura do velocino de ouro, buscam restituir utopicamente, por meio da violência, a dignidade humana perdida pela burguesia e por seu sistema de consumo, embora eles próprios façam parte dessa burguesia em 
ruínas e a partir dela, e somente com ela, haja a possibilidade deles, pobres meninos ricos, serem uma gangue e uma gangue opositora à burguesia. Ou seja, é a burguesia que moralmente corrompe o homem, mas que também o encoraja a se opor a ela: "O Rospo fica macambúzio: procura ferozmente uma desculpa moralista para a sua acção, uma razão profunda que justifique a sua revolta, uma razão hipócrita, conformista e, por isso, ainda mais dolorosa" (PASOLINI, 2016, p. 120). Uma desculpa que não pode ser encontrada dada a tragicidade da época moderna: o trágico na modernidade está exatamente nesse evento sem saída (não se pode sair da burguesia), no qual o herói se encontra aprisionado a um destino já prefigurado (o destino burguês), a tentativas fracassadas de se opor a esse destino (falsas justificações morais) e a um sofrimento angustiante (saber que não se pode escapar ao que lhe foi vaticinado). Desse modo, o trágico na modernidade é a própria condição burguesa, que, por sua vez, insere o herói em uma crise (saber-se um burguês) da qual ele não pode de modo algum escapar, ou melhor, pode até escapar, mas por meio de sua própria morte. Em A nebulosa, uma cartomante, gorda e acabada, vaticina a irrefutabilidade do destino trágico da gangue dos teddy boys:

MULHER Malvados sem-vergonha... [refere-se à gangue que acabara de roubar o seu marido] (cala-se mais uma vez, enquanto dispõe as cartas na mesa) Não vês que têm o diabo no corpo? (Começa a consultar o futuro) Mas o que é que pensas? Antes de amanhecer... se continuarem assim... vão pagá-las... digo-to eu... (concentrada, muda as cartas de posição) Antes do amanhecer... um deles, pelo menos... bate a bota... (PASOLINI, 2016, p. 61, grifos do autor)

Vale destacar que a concepção fílmica-escrita, as locações-ambiente e os atores-personagem de $A$ nebulosa estão esvaziados de qualquer aspecto do puramente belo, pois tudo se encontra gasto, vilipendiado, a beleza das grandes mansões burguesas está conspurcada por seus moradores, as ruas, as vielas e as avenidas de Milão estão sujas, cheias de entulhos, o belo corpo dos rapazes esconde uma perecibilidade gratuita e as casas burguesas não podem mais esconder a sua decrepitude, o seu fim: "O Rospo e Mosè sobem um lanço de escadas. Escadas tristes de um prédio velho, com a sua antiga dignidade art nouveau decadente, corroída por gerações de famílias pequeno-burguesas em luta com o salário" (PASOLINI, 2016, p. 161, grifo do autor). Por mais que o narrador insista nas cores aberrantes das placas em néon dos bares e boates que são visitados pela gangue, o que se deixa entrever, 
na verdade, sob a sua fala, é uma tonalidade cinza-escuro, branco-amarronzado e preto-ofuscante: "Só as luzes continuam a arder, vívidas e incandescentes, no breu gélido" (PASOLINI, 2016, p. 157). Como podemos observar, o que prevalece é o breu, jamais a luz ou a cor. Essa paleta, digamos, monocromática, prevalece em todo o desenvolvimento do livro-filme, que se inicia ao entardecer e finda tragicamente com o amanhecer, com uma morte ao amanhecer. Uma cor ambiente que não cede ao colorido, mas ao escuro, ao marginal, ao escondido, ao túnel, ao buraco, à noite. Em relação à temporalidade narrativa, os eventos de $A$ nebulosa, tomando de empréstimo o tempo mítico das tragédias clássicas, se passam no decorrer de uma única noite, a última noite do ano: "a tragédia é uma questão de kairos, de tempo cobrado, atormentado por uma crise, repleto de verdade momentosa" (EAGLETON, 2013, p. 253, grifo do autor). De modo semelhante ao kairos trágico clássico e diferente do chronos do romance, $A$ nebulosa resgata essa unicidade do tempo mítico que, por estar todo prefigurado, não abre espaço para a liberdade da ação, mas sim para a confirmação do destino anteriormente selado do herói, uma vez que, não podendo não ser burguês, a gangue não poderá jamais deixar de ser parte da burguesia decadente italiana: "Por ter conteúdos prefigurados, o tempo mítico não guarda lugar para a liberdade" (SCHWARZ, 1981, p. 64). E o final do drama de Pasolini sela o destino dos heróis prefigurado pela cartomante-vidente:

Com efeito, a luz é cada vez mais intensa - e mais triste. [...] O Teppa põe as mãos em concha à volta da boca e, com um olhar risonho, pleno de amor e de juventude, começa a gritar:

TEPPA Daniela! Daniela! Abre, é só um instante! Quero ver-te!

Disparo de revólver.

O Teppa estatela-se no chão, inerte.

Por instantes, os outros não percebem o que se passa. Depois, impera um profundo silêncio.

Os seus rostos voltam-se, contra aquele céu carregado de uma luz triste, para o corpo do Teppa. Nos seus olhos, instalam-se o terror e a dor.

Toni lança-se sobre o corpo do amigo, abanando-o desesperado: o peito está encharcado em sangue.

TONI (com um grito desesperado) Teppa! (PASOLINI, 2016, p. 198-89, grifo do autor)

À irrefutabilidade ficcional do destino dos rapazes de $A$ nebulosa, soma-se a irrefutabilidade real do destino dos rapazes italianos. Em "O verdadeiro fascismo e portanto o verdadeiro antifascismo", de 1974, Pasolini retoma a questão do destino 
predeterminado para refletir sobre os jovens fascistas italianos, declarando a sua mea culpa e a de grande parte da sociedade italiana que nada fizeram para barrar a entrada desses jovens no regime fascista, por acreditarem que esses jovens já tivessem nascido predispostos, por uma contingência que escapa à razão, a aderir a tal forma de pensar e de agir politicamente: "Na realidade nos comportamos com os fascistas (refiro-me sobretudo aos jovens) de maneira racista: quer dizer, quisemos apressada e impiedosamente crer que estavam predestinados por sua raça a serem fascistas, e perante essa decisão do seu destino não havia nada a fazer" (PASOLINI, 2020, p. 8283). E conclui: "todos sabíamos, em nossa sã consciência, que era por puro acaso que um daqueles jovens decidia ser fascista, que se tratava de um mero gesto imotivado e irracional" (PASOLINI, 2020, p. 83, grifo do autor). Um destino, como sabemos, orquestrado pelo sistema burguês de consumo, que, aliás, é o que torna a nossa modernidade, segundo Eagleton, profundamente trágica. É a partir da dialética entre um idealismo impotente, um utopismo socialista, para retomar a crença de Pasolini, e uma realidade em ruínas, torpemente consumista, fomentada pela ordem social burguesa e incapaz de ser resolvida por ela, que podemos declarar a nossa modernidade trágica. Mais uma vez, não há saída para o evento trágico, fim: "Aceitamo-los rapidamente como inevitáveis representantes do Mal" (PASOLINI, 2020 , p. 83). O fascismo aderido pelos jovens italianos e a violência aderida pelos teddy boys de $A$ nebulosa foram modos, ou tentativas, de buscar uma saída, impossível, para a desilusão política e social de suas respectivas sociedades, embora esses modos tendessem sempre a fracassar, pois sair da sociedade burguesa somente poderia se dar pela morte: "ROSPO Que nojo de sociedade! Aparentemente tão limpa, e por baixo é só podridão, podridão, podridão... Ah, não suporto esta cambada de porcos burgueses conformistas... Esta noite, sangue!" (PASOLINI, 2016, p. 123).

Essa desilusão trágica, como comprova Eagleton, resulta da descrença do homem moderno diante da não realização eficaz das propostas positivistas e iluministas asseguradas pela burguesia quando da sua ascensão. De fato, o sistema burguês não pôde mantê-las, a bem da verdade, sucumbira e se tornara refém do que construíra, o capitalismo: "A burguesia não pode desistir de seus ideais, mas também não pode concretizá-los; e, quanto menos ela pode fazê-lo, mais impalatáveis e abstratos eles se tornam" (EAGLETON, 2013, p. 293). Pasolini e Eagleton concordam quando, cada um à sua maneira, creditam o sentimento trágico à desilusão e ao 
pessimismo causados no homem moderno pela desesperança provocada pelo seu meio social burguês: "ROSPO Olha para ela, a nossa classe dirigente, atolada na merda até o pescoço... estes democratas-cristãos beatos e oportunistas... Divertemse, hem, na cara do povo..." (PASOLINI, 2016, p. 187). É interessante ressaltar que, embora seja uma gangue justiceira, a favor da retomada da humanidade perdida, os teddy boys são um produto do meio burguês, sendo eles próprios um efeito torpe e contraditório, moralmente falando, da ruína burguesa: "O semblante [de Rospo] ensombra-se-lhe de novo, com a surda crueldade de quem inventa justificações morais para os seus actos e com o desespero de quem sofre, realmente, de uma confusa repressão moral" (PASOLINI, 2016, p. 123). Pasolini não renuncia à complexa ambiguidade dos atos e nem à complexa ambiguidade da formação do caráter de seus rapazes de "beleza viril posta a descoberto" (PASOLINI, 2016, p. 96). Em $A$ nebulosa, o objetivo é, antes de tudo, impossibilitar qualquer pré-conceito em relação aos atos violentos da gangue, como se houvesse também valor e aprendizado no mal e no sofrimento, e não apenas no bem e na felicidade: "A tragédia pode nos mostrar que é possível liberar valor no ato da própria destruição, para que [...] saboreemos a opulência de uma coisa no próprio momento de sua ruína" (EAGLETON, 2013, p. 56).

São sete os atos violentos da gangue dos teddy boys: o roubo das joias da estátua da Virgem da igreja de Val Padana seguido da surra no sacristão; o roubo do dono da venda na periferia de Milão; o quebra-quebra dos objetos da mansão dos marqueses de Valtorta; o sequestro de três senhoras casadas seguido de assédio sexual; a violenta humilhação e surra em um homem que estava se relacionando em seu carro com uma menina menor de idade; a humilhação de um homossexual que fora despido e deixado sozinho em um campo desolado; e a luta entre a gangue e os burgueses em uma boate luxuosa de Milão. Quando da investida da gangue, a grande maioria das vítimas parece reconhecer sua parcela de culpa no colapso moral da sociedade, deixando-se violar, como as senhoras casadas, ou deixando-se golpear e humilhar, como no caso do homem com a menor: "ROSPO Não tens mesmo vergonha? Que raio de homem és tu? Nem sequer tentas rebelar-te... Estás mesmo a pedir mais... Que dizem, rapazes? O que é que fazemos com este pobre diabo?" (PASOLINI, 2016, p. 136). Apenas uma vítima, o homossexual Gino, é quem os enfrenta e, por enfrentá-los e desarmá-los moralmente, tem o seu castigo abrandado, não sendo violentado e nem esmurrado, somente despido e deixado em um campo deserto: "GINO Vocês não são infelizes, são infelicíssimos. Odeiam os vossos pais e 
o mundo deles, ou seja, a sociedade; mas não os odeiam suficientemente... porque, no fundo, são iguais a eles..." (PASOLINI, 2016, p. 149-50). Gino, por saber estar à margem da sociedade, é aquele que pode dizer da margem que habita os demais homens. E, como sabemos, a verdade intimida e acovarda, pois nos coloca frente a frente com o que desejamos esconder de nós e do mundo. Porém, há aqueles que, violentados socialmente em seu dia a dia, como os homossexuais, têm na verdade o sopro da sobrevivência cotidiana, ao saber quem são e o que desejam ser de fato: "TONI Querem ver que encontrámos um profeta? / GINO Profeta? Nada disso... Mais um infeliz como vocês, mas que pelo menos reconhece que o é..." (PASOLINI, 2016, p. 151).

Pasolini, em "A prisão e a fraternidade do amor homossexual", manifesta-se de forma lírica, talvez partindo de seu lugar de fala, enquanto poeta e homossexual, sobre o aprendizado que resulta do amor homossexual: a verdadeira tolerância, uma vez que, jamais sendo aceitos, mas tolerados parcialmente pela sociedade de consumo, os homossexuais são aqueles que, pela dor da não aceitação, sabem compreender a dor do outro e toleram realmente o outro diferente, aquele que pode estar, como eles, à margem:

Quem exprimiu - mesmo numa situação de emergência - a própria homossexualidade (amparado por uma coragem certamente mais popular do que burguesa - e daí a conotação classista do ódio contra a homossexualidade) não será nunca mais, ao menos nesse campo, racista e perseguidor. Na sua experiência humana existirá um elemento de tolerância "real" a mais, que não existia antes. E, no melhor dos casos, terá enriquecido o seu conhecimento das pessoas do seu próprio sexo, com quem suas relações só podem, fatal e naturalmente, ser de caráter homoerótico, tanto no ódio como na fraternidade. (PASOLINI, 2020, p. 241)

Alberto Moravia, em um belo texto, "A ideologia de Pasolini”, nos diz, como apenas os grandes amigos podem dizer de nós, que:

No início, havia a homossexualidade, concebida, porém, da mesma forma que a heterossexualidade, isto é, como relação com o real, como stendhaliana cristalização, como fio de Ariadne no labirinto da vida. Pensemos apenas por um momento na fundamental importância que sempre teve na cultura ocidental o amor, como ele inspirou as grandes construções do espírito, os grandes sistemas cognitivos; e se perceberá que a homossexualidade cumpriu na vida de Pier Paolo Pasolini a mesma função que teve a heterossexualidade em tantas 
outras vidas, não menos intensas e criativas que a sua. (MORAVIA, 2011, p. 01)

E se apenas Freud "é capaz de explicar o que seja a homossexualidade" (PASOLINI, 2020, p. 244), retomemos, então, o psicanalista em uma carta dirigida a uma mãe de um homossexual:

A homossexualidade certamente não é uma vantagem, tampouco é algo de que se envergonhar, não é nenhum vício, nenhuma degradação, não pode ser classificada como doença; nós a consideramos uma variação da função sexual produzida por uma detenção no desenvolvimento sexual. Muitos indivíduos altamente respeitáveis, tanto da Antiguidade quanto de tempos modernos, foram homossexuais, vários dos maiores entre eles (Platão, Michelangelo, Leonardo da Vinci, etc.). É uma grande injustiça, e também uma crueldade, perseguir a homossexualidade como se ela fosse um crime. (FREUD, 2018, p. 349)

Embora a ciência, a psicanálise e a cultura enfatizem que "uma relação homossexual não é o Mal, ou melhor, não há nada de mal numa relação homossexual" (PASOLINI, 2020, p. 240), ainda assim o centralismo da sociedade de consumo, em sua ânsia pela padronização enquanto método mais eficaz para o pleno domínio do humano, exclui o ser diferente, menospreza-o, humilha-o. E, aliado ao consumo, o regime político pode também exercer um poder de exclusão, como o que está ocorrendo, por exemplo, em nossa atualidade política brasileira. Em A nebulosa, Rospo, ao se referir aos homossexuais, vocifera: "Se fosse eu quem mandasse na polícia, veriam como elas mordem! Enfiava-os todos nas câmaras de gás... Nos fornos crematórios... Maldita gente, são a ruína da sociedade!" (PASOLINI, 2016, p. 143). Através de Rospo, Pasolini escancara a intolerância burguesa em relação aos homossexuais como um modo de fazer com que o leitor-espectador reflita e tire da violência do personagem um valor e um saber, passando a compreender que o outro, apenas por ser o outro, não deve ser eliminado do meio social ou ser visto como uma coisa menor, inferior. É por essa razão que, em $A$ nebulosa, a vítima tida como a mais inferior e a mais passível de ser imolada é aquela que sobrepuja a força da gangue e os expõe à sua farsa: uma superioridade falsa promovida por uma sociedade burguesa que, a bem da verdade, apenas visa o lucro e dita a heterossexualidade como o modelo a ser seguido para que, no fim, o padrão vença e suplante a minoria: 
"Por momentos, todos ficam em silêncio, atónitos - se bem que não o mostrem - com a força da verdade adivinhada por Gino" (PASOLINI, 2016, p. 150).

Com $A$ nebulosa, Pasolini demarca o verdadeiro lugar da literatura em uma sociedade de consumo: o lugar de uma força crítica, impetuosa, que não se subjuga ao "novo Poder", que combate toda e qualquer forma de padronização dos costumes e das ações humanas, e que luta, por fim, pela individualidade e pela independência do homem. À era do consumo, que ilude os homens, que os torna ignorantes e que Ihes arruína a alma, a literatura responde com a inteligência, ao restituir-lhes, através da escrita literária e da leitura, o poder do pensamento. De homem-massa que fora, para espírito livre que virá a ser. Fim.

\section{Referências}

AMOROSO, Maria Betânia. Pasolini escritor-crítico em Descrizioni di descrizioni. Revista Passagens, v. 07, n. 02, p. 97-107, 2016. Disponível em: http://periodicos.ufc.br/passagens/article/view/6271. Acesso em: 26 nov. 2020.

ARENDT, Hannah. A condição humana. Tradução Roberto Raposo. Rio de Janeiro: Forense Universitária, 2007.

BAUDRILLARD, Jean. A sociedade de consumo. Tradução Artur Morão. Lisboa: Edições 70, 1995.

CAMUS, Albert. A peste. Tradução Valerie Rumjanek Chaves. Rio de Janeiro: Record, 2018.

EAGLETON, Terry. Doce violência: a ideia do trágico. Tradução Alzira Allegro. São Paulo: Editora Unesp, 2013.

FONTENELLE, Isleide Arruda. O estatuto do consumo na compreensão da lógica e das mutações do capitalismo. Revista Lua Nova, n. 92, p. 207-240, maio-ago. 2014. Disponível em: https://www.scielo.br/pdf/ln/n92/a08n92.pdf. Acesso em: 25 nov. 2020.

FREUD, Sigmund. Carta a uma mãe preocupada com a homossexualidade de seu filho (1935). In: FREUD, Sigmund. Amor, sexualidade, feminilidade. Tradução Maria Rita Salzano Moraes. Belo Horizonte: Autêntica Editora, 2018, p. 349-350.

HOLLANDA, Heloisa Buarque de. Explosão feminista: arte, cultura, política e universidade. São Paulo: Companhia das Letras, 2018.

HUGO, Victor. Do grotesco e do sublime. Tradução Célia Berrettini. São Paulo: Perspectiva, 2014. 
MORAVIA, Alberto. A ideologia de Pasolini. Tradução Stella Rivello. Revista InTraduções, v. 03, n. 04, p. 1-10, jan. 2011. Disponível em: https://periodicos.ufsc.br/index.php/intraducoes/article/view/62246. Acesso em: 12 set. 2020.

NIETZSCHE, Friedrich. Além do bem e do mal. Tradução Paulo César de Souza. São Paulo: Companhia das Letras, 2005.

PASOLINI, Pier Paolo. Poemas: Pier Paolo Pasolini. Tradução Maurício Santana Dias. São Paulo: Cosac Naify, 2015.

PASOLINI, Pier Paolo. A nebulosa. Tradução Manuela Gomes. Lisboa: Antígona Editores Refractários, 2016.

PASOLINI, Pier Paolo. Análise linguística de um slogan. In: PASOLINI, Pier Paolo. Escritos corsários. Tradução Maria Betânia Amoroso. São Paulo: Editora 34, 2020, p. 42-46.

PASOLINI, Pier Paolo. Aculturação e aculturação. In: PASOLINI, Pier Paolo. Escritos corsários. Tradução Maria Betânia Amoroso. São Paulo: Editora 34, 2020, p. 53-56.

PASOLINI, Pier Paolo. Vazio de Caridade, vazio de Cultura: uma linguagem sem origens. In: PASOLINI, Pier Paolo. Escritos corsários. Tradução Maria Betânia Amoroso. São Paulo: Editora 34, 2020, p. 66-70.

PASOLINI, Pier Paolo. O verdadeiro fascismo e portanto o verdadeiro antifascismo. In: PASOLINI, Pier Paolo. Escritos corsários. Tradução Maria Betânia Amoroso. São Paulo: Editora 34, 2020, p. 78-83.

PASOLINI, Pier Paolo. Ampliação do "esboço" sobre a revolução antropológica na Itália. In: PASOLINI, Pier Paolo. Escritos corsários. Tradução Maria Betânia Amoroso. São Paulo: Editora 34, 2020, p. 90-96.

PASOLINI, Pier Paolo. O romance dos massacres. In: PASOLINI, Pier Paolo. Escritos corsários. Tradução Maria Betânia Amoroso. São Paulo: Editora 34, 2020, p. 120-126.

PASOLINI, Pier Paolo. A prisão e a fraternidade do amor homossexual. In: PASOLINI, Pier Paolo. Escritos corsários. Tradução Maria Betânia Amoroso. São Paulo: Editora 34, 2020, p. 236-241.

PASOLINI, Pier Paolo. M. Daniel e A. Baudry: Os homossexuais. In: PASOLINI, Pier Paolo. Escritos corsários. Tradução Maria Betânia Amoroso. São Paulo: Editora 34, 2020, p. 242-248.

PICCININI, Alberto. O lado teddy boy de PPP. In: PASOLINI, Pier Paolo. A nebulosa. Tradução Manuela Gomes. Lisboa: Antígona Editores Refractários, 2016.

SCHWARZ, Roberto. A sereia e o desconfiado. Rio de Janeiro: Paz e Terra, 1981. 
SÓFOCLES. Édipo Rei de Sófocles. Tradução Trajano Vieira. São Paulo: Perspectiva, 2016.

VARGAS, Mateus. Prazo de validade pode levar governo federal a jogar fora 6,8 milhões de testes. O Estado de S. Paulo, São Paulo, 22 de nov. 2020. Caderno de Saúde. Disponível em: https://saude.estadao.com.br/noticias/geral,prazo-devalidade-pode-levar-governo-federal-a-jogar-fora-6-8-milhoes-detestes, 70003523522 . Acesso em: 26 nov. 2020.

ŽlŽEK, SLAVOJ. A visão em paralaxe. Tradução Maria Beatriz de Medina. São Paulo: Boitempo, 2008. 